\title{
Agreement and syncretism in Esahie ${ }^{1}$
}

\author{
Obed Nii Broohm \\ Doctoral Researcher \\ Department of Culture and Civilization \\ University of Verona, Italy. \\ Email: obednii.broohm@univr.it; onbroohm@gmail.com
}

\author{
Stefan Rabanus \\ Associate Professor of Linguistics, \\ Department of Foreign Languages and Literatures \\ University of Verona, Italy. \\ Email: stefan.rabanus@univr.it
}

Submitted: November 7, 2017 / Accepted: May 15, 2018 / Published: June 8, 2018

\begin{abstract}
This paper investigates the inflectional system of the nominal domain in Esahie (Central-Tano, Kwa, Niger-Congo) by focusing on agreement and syncretism. It offers a comprehensive description of these inflectional phenomena in an attempt to test and account for the strength of the inflectional system of an otherwise under-described language. It shows among other things that morpho-syntactic features including number, person, animacy, and case, all enter the Esahie agreement system in various contexts. Adopting Corbett's (2006) criteria for canonicity of agreement, this work demonstrates that, in Esahie, DP-internal agreement is more canonical than anaphora agreement. A general paucity of inflection marking is argued to account for the several instances of syncretism in Esahie. Furthermore, this work demonstrates that syncretism is pervasive in the pronominal system of Esahie. Collected largely through elicitation from native speakers, the Esahie data discussed in this work provides empirical support for the irreducibility hypothesis proposed by Stump (2016). Hence, on the theoretical level, this work argues for adopting a paradigm-based approach to inflectional morphology over a morpheme-based approach to inflectional morphology.
\end{abstract}

Keywords: Esahie, agreement, syncretism, inflectional morphology, paradigm

$1 \mathrm{We}$ are grateful to the three anonymous reviewers of the Legon Journal of the Humanities for their insightful comments on an earlier version of this paper that have greatly improved on the general quality and outlook of the paper. We would also like to thank Chiara Melloni, Greville G. Corbett, Clement K. I. Appah, Sylvia Esi Andam, David Broohm and participants of 2018 ACAL 49 Conference for their various contributions. We are solely responsible for any remaining shortcomings. 


\section{Muaboledwire}

So krataa he te krataa bo oniania dumaa nwõ dwire nu inflekhyin wo Esahie (Tano-Afĩa, Kwa, Niger-Kongo) dwudwole nu bo ogyi agriiment ne sinkritisim soo. Krataa he botae

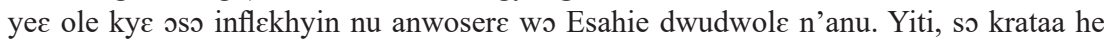

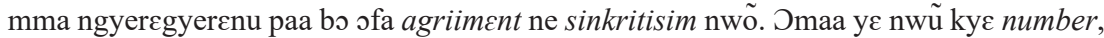
person, animacy ne kase nkoraatiii wura Esahie agriiment nu dwire wo nekaa sorõyo

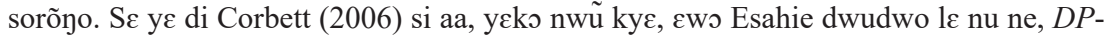

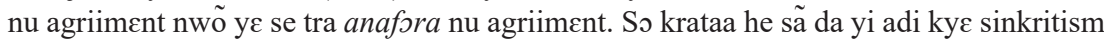

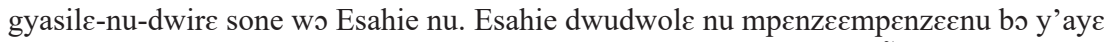

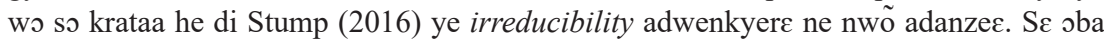

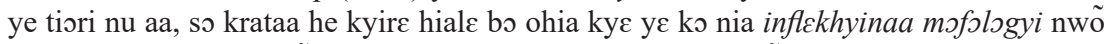

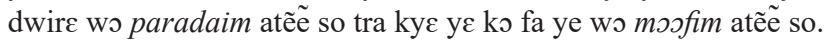

Nzemfua titiri: Esahie, agriiment, sinkritisim, inflekhyinaa mofっlogyi, paradaim.

\section{Introduction}

This paper sets out to investigate and provide a comprehensive description of agreement and syncretism in Esahie, a minority language of Ghana ${ }^{2}$ (and Cote d'Ivoire) which is highly understudied, especially in the domain of morphology ${ }^{3}$. By means of this description, we hope to test, and provide an account of, the strength of the inflectional system especially of the nominal domain in Esahie, hence we focus on an aspect which has been ignored in previous research (cf. Grammatical properties/Sociolinguistics of Esahie section), as an attempt to fill a gap in the literature. ${ }^{4}$

On the theoretical level, we will provide evidence in favor of a paradigm-based approach to inflectional morphology, in which paradigm structure is seen as crucial in defining a language's inflectional morphology, rather than a morpheme-based approach to inflectional morphology, in which paradigms are seen as

2 The 2013 speaker population statistics (i.e. the number of speakers per language) as provided by Ethnologue (www.ethnologue.com) for Ghana, reports 299,000 speakers for Nzema, 305,000 speakers for Esahie, 745,000 speakers for Gã, 1,160,000 speakers for Dagbani, 3,820, 000 speakers for Ewe, and 9,100,000 speakers for Akan.

3 Apart from the work on the noun class system (Broohm 2017), the (inflectional) morphology of Esahie has not been explored at all.

4 In this paper we use the standard abbreviations listed in the Leipzig Glossing Rules $<$ https:// www.eva.mpg.de/ lingua/pdf/Glossing-Rules.pdf $>$ and additionally:

\begin{tabular}{|c|c|c|c|c|c|}
\hline ANIM & Animate & AUG & Augmentative & & Clause-final determiner \\
\hline $\mathrm{CONJ}$ & Conjunction & DP & Determiner phrase & HAB & Habitual aspect marker \\
\hline IA & Item-and-Arrangement & INT & Intensifier & NOML & Nominalizing affix \\
\hline $2 \mathrm{P}$ & Resumptive pronoun & SVO & Subject Verb Object & & \\
\hline
\end{tabular}


merely epiphenomena of morphotactics and consequently playing no significant role in the definition of a language's inflectional morphology.

The paper is structured as follows: we first present the theoretical framework that grounds this work, and introduce Stump's (2016) irreducibility hypothesis. Next, we provide a brief grammatical and sociolinguistic overview, in order to situate Esahie in its proper typological setting, and proceed to give an overview of previous research in morphology (morphological theory). We then introduce the notion of agreement, spell out what constitutes canonical agreement (Corbett 2006), and proceed to compare and contrast two types of agreement in Esahie with respect to canonicity: $D P$-internal agreement and anaphora agreement. Subsequently, we discuss syncretism and how it can be typologized from an explanatory perspective, focusing on two kinds of syncretisms that obtain in the nominal domain of Esahie.

\section{Theoretical framework}

Traditionally, the function of inflection, as opposed to derivation, has been widely viewed as a mechanism for encoding phrase-level properties and relations on its heads, which are (inflected) word forms (cf. Stump 2001). Structural relations such as government and agreement are sensitive to inflectional categories (such as number, person, case, gender) and its features (e.g., "plural", "first person", "accusative", "feminine") which are organized into inflectional paradigms.

In morphology, there are basically two theoretical approaches to inflectional paradigms: morpheme-based approaches ${ }^{5}$ in which paradigms are simply ways to visualize different word forms without any further theoretical relevance, and paradigm-based approaches in which inflectional morphology makes essential reference to the structure of paradigms. In the morpheme-based

5 In morpheme-based theories, the morpheme is seen as the basic unit for morphological analysis. The Item-and-Arrangement theory (Hockett, 1954) is one of such morpheme-based theories. An underlying assumption of this (concatenative) theory is that in an "ideal" morphological system, each morpheme contributes/bears one and only one meaning, and each meaning is associated with one and only one morpheme. 
approach, the "grammatical and semantic content of an inflected word form is fully determined by its representation as a combination of morphemes" (Stump, 2016, p. 13). For example, the meaning of the Italian past tense (preterite) verb ballavo 'I danced' is conceived as sum of the meanings of the three morphemes the word can be segmented into, as shown in (1).

(1) balla-v-o

dance-PST-1 SG

"I danced."

In this approach, which Stump (2001, p. 1-3) labels "lexical-incremental", morphology is seen as word-internal syntax (Lieber, 1992, vii) and not as an autonomous component of grammar, distinct from syntax. This approach is able to adequately describe words formed by concatenative exponents like the ones in (1). However, our analysis will show that the approach does not provide an adequate account of other types of formal exponence. The lexical-incremental approach may be represented in the form of (2a) where the arrow means "determines", hence: the three morphemes determine the grammatical and semantic properties expressed by the word ballavo, i.e., "I danced".

a. balla 'dance' $+v$ PST $+o 1 \mathrm{sG} \rightarrow$ "I danced."

b. "I danced." $\rightarrow$ balla- $v-O$

In the paradigm-based approach ("inferential-realizational", according to Stump's [2001, p. 1-3] classification), on the contrary, the order of determination is reversed, as represented by (2b). In this approach, it is not the morphemes that determine the grammatical and semantic content of the word. Rather, it is the properties of the word which determine the formal exponents, or, as Stump (2001, p. 32) puts it, 'a word's association with a particular set 
of morphosyntactic properties determines a sequence of rule applications defining that word's inflectional form." The location where this association takes place is the paradigm. The paradigm cell determines which formal exponents are necessary in order to express the properties: they may be concatenative morphemes as in (1), processes such as umlaut, ablaut or reduplication (as in [15b], cf. DP-internal Agreement section), or the assignment of specific tones. If two paradigm cells determine the same rules for formal exponence syncretism occurs (cf. Syncretism section).

This is where the irreducibility hypotheses originates from (cf. Stump 2016). "The irreducibility hypothesis entails that there are morphological significant generalizations that are, irreducibly, about whole word forms and their content (about paradigm cells)" (Stump, 2016, p. 27). Put differently, some generalizations or regularities in a language's inflectional system cannot be attributed to any specific aspect of the word form but only to paradigm structure, among which are certain instantiations of agreement, and syncretism. The match between syntax and morphology is apparent where elements within a syntactic domain show agreement. By contrast, syncretism is a reflection of a mismatch between syntax and morphology. In this sense, both phenomena, agreement and syncretism, are strongly connected and will be analysed here in order to provide evidence in favour of the paradigm-based approach.

\section{Grammatical properties/Sociolinguistics of Esahie: State of the art}

Esahie has been alternatively referred to as Asahyue, Sanvi, Sefwi, and Sehwi, and coded in Ethnologue as [ISO 639-3: sfw]. Esahie belongs to the Northern Bia family of the Central-Tano subgroup (Dolphyne \& Dakubu, 1988). Esahie is genetically close to Aowin and Nzema and falls in the same language family as Anyi as shown in the Kwa language family tree in Figure 1 below. 
Broohm, O. N. and Rabanus, S./ Legon Journal of the Humanities 29.1 (2018)
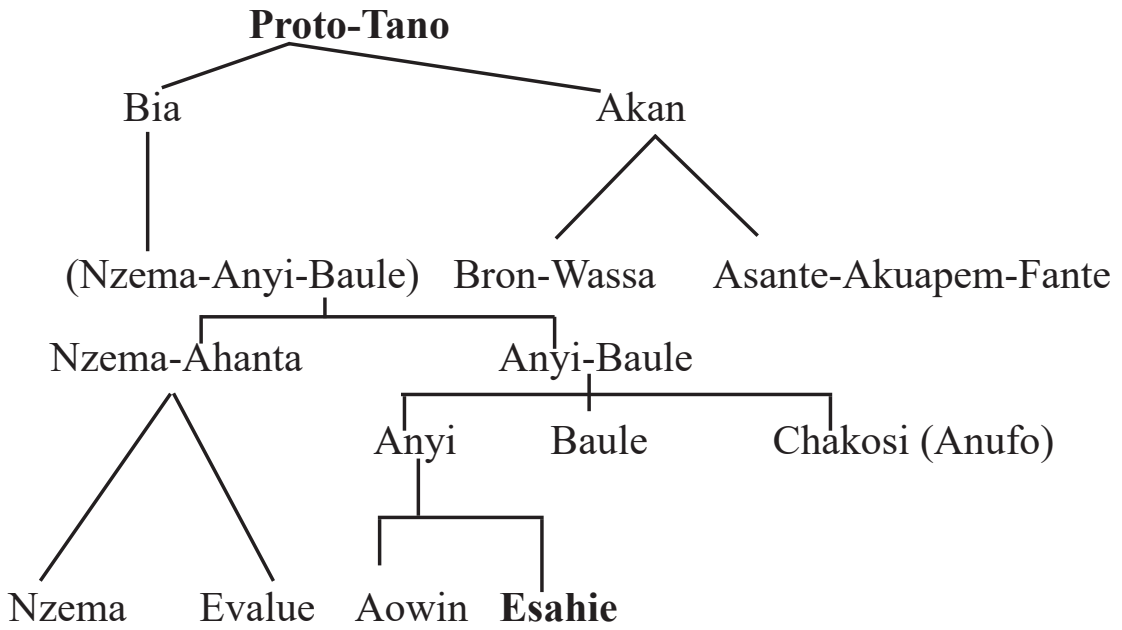

Figure 1: Kwa language family tree (Dolphyne \& Dakubu, 1988, p. 56)

As shown in Figure 1, the first split under the Bia language group is between Nzema and Ahanta, on one side, and Anyi and Baule, on the other side. Thereafter, Anyi, Baule, and Chakosi split from each other. Anyi then also splits into Anyi (Aowin) and Esahie (Sehwi). There are two dialects of Esahie (Ntumy \& Boafo, 2002). The Anhwiaso dialect, which is spoken in the extreme east of the area, that is, east of the River Subraw in towns like SehwiAnhwiaso, Sehwi-Bekwai, and Asawinso, and the Wiawso dialect, which is the major variety in use, in the wider area, westwards of the River Subraw. Data used in this work are mainly drawn from the latter variety.

In terms of phonological features, Frimpong (2009) points out that Esahie is a tonal language with two basic contrastive tones: a high tone (relatively high pitch) marked with an acute accent ('), and a low tone (relatively low pitch) marked with a grave accent (' ), adding that tone plays both grammatical and lexical roles ${ }^{6}$.

6 In terms of grammatical roles, tone in Esahie may be employed to signal various T-A-M and polarity values 
Syntactically, Esahie, like Akan, and indeed many other Kwa languages (Broohm, 2014; Aboh \& Essegbey, 2010a), is a strictly SVO language. As a nominative-accusative language, the agent precedes the verb and the patient follows the verb in a simple transitive clause (see 3a). The subject of an intransitive clause also precedes the verb, as exemplified in (3b).
a. Salo
po-le
ataade $\varepsilon$
ne.
Salo[SBJ]
wash-PST
dress[OBJ]
DEF
"Salo washed the dress."
b. David la-le.
David[SBJ] sleep-PST
"David slept."

Morphologically, it would be most suitable to categorize Esahie as typologically and predominantly isolating, in consonance with what has been observed generally for Kwa (Broohm, 2017; Aboh \& Essegbey, 2010b). As such, one characteristic feature of Esahie is that it has a fairly limited inflectional morphology. Consequently, lexical DPs are not inflected for case, but only for number, as is seen in example (4).
a. $\quad \mathrm{Kyía}^{7}$
a-hye
e-bote.
$\operatorname{dog}$
PFV-catch
SG-rabbit
"A dog has caught a rabbit."

b. E-bote a-hye kyía.

SG-rabbit PFV-catch dog

"A rabbit has caught a dog."

7 kyía 'dog' is zero-marked in the singular. 
It is instructive to mention, however, that the Esahie pronouns inflect for case (nominative, accusative). Notwithstanding the case-sensitivity exhibited by the pronominal system, Broohm (2017) observes that, relatively speaking, Esahie has suffered a stronger deal of morphosyntactic decay especially in its nominal inflection system, resulting in a general paucity of inflection marking. This observation is crucial because the two phenomena under investigation in this paper both involve inflection marking.

\section{Agreement}

Alternatively referred to as concord, agreement has been defined as "some systematic covariance between a semantic or formal property of one element and a formal property of another" (Steele, 1978, p. 610). Essentially, agreement has to do with the (morphological) matching of feature values between two separate elements within a certain syntactic domain.

While the element which triggers or determines the agreement has been referred to as the controller, the element whose form is determined by the agreement, on the other hand, has been referred to as the target, and the syntactic context in which agreement occurs has also been referred to as domain (Corbett 2003, p. 198). Agreement features refer to the specific attribute or property around which agreement revolves, i.e., the morphosyntactic property in which the agreeing elements covary. Case, as an agreement feature, could have several values including "nominative", "accusative", "dative", "instrumental", and so on, depending on the language. Figure 2 provides a summary of the relevant aspects of agreement, as discussed above. 


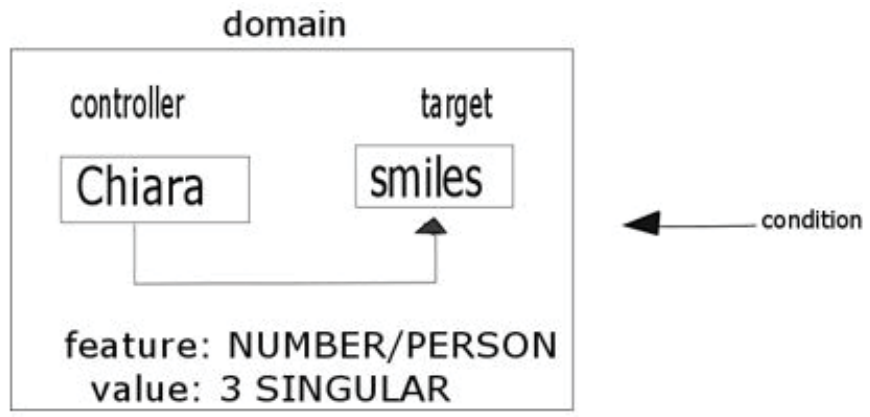

Figure 2: Agreement model (adapted from Corbett, 2006, p. 5)

Having introduced some of the relevant aspects of the phenomenon of agreement, we shall now proceed to illustrate it with examples from European languages. In the English example (5), the noun file functions as the controller whilst the demonstrative functions as the target. Similarly, in (6) the predicate loves (target) agrees with the subject John (controller) with respect to number and person. In the French and Italian examples below, there is gender/number agreement between the noun and definite article (in [7]) and gender agreement between the noun, indefinite article and modifying adjective (in [8]). The targets of (6-8) are characterized by concatenative morphology, the target in (5), these, is not: in (5) number is expressed by vowel and consonant alternations (this [ðIs] SG vs. these [ði:z] PL; transcriptions for British English).

(5) these file-s.

DEM.PL file-PL - Number Agreement (English)

"These files."

(6) John love-s candie-s.

John[SG] love-3SG candy-PL - Number/Person Agreement (English)

"John loves candies." 
(7) $\quad 1-\mathrm{a}$

DEF-SG.F

"The table."
Broohm, O. N. and Rabanus, S./Legon Journal of the Humanities 29.1 (2018) table.

$\operatorname{table}(\mathrm{F})[\mathrm{SG}]$ - Gender Agreement (French)

(8)

un-a bell-a casa.

INDF-SG.F beautiful-SG.F house(F)[SG] - Gender/Number Agreement (Italian)

"A beautiful house."

From the examples given above, we observe that the domain of agreement could be the DP (as in [5], [7], [8]) as well as a higherorder structure (e.g., the clause, as in [6]).

The gamut of syntactic relations that can be signalled via agreement morphology varies cross-linguistically. Since agreement varies within and across language(s), some patterns of agreement may be seen as epitomizing more "canonical" cases of agreement than others. Consequently, there has been a debate on whether or not anaphora relations (i.e., the determination of the form of anaphoric pronouns) also forms part of agreement. As Corbett (2003) notes, over the years, there has been a growing consensus in the literature that anaphora relations can be analysed in terms of agreement morphology. As a follow-up to this, Corbett (2006) proposes indicators that constitute the criteria for defining the relevant aspects of "canonical agreement" (i.e., prototypical cases of agreement), such that if any agreement pattern falls short of this, that pattern may be described as "non-canonical". Corbett's main criteria are summarised in Table 1. 
Broohm, O. N. and Rabanus, S./ Agreement and syncretism in Esahie

Table 1: Selection of Corbett's canonicity criteria (Corbett, 2006,

p. 8-27)

\begin{tabular}{|l|l|l|l|l|}
\hline Controllers & Targets & Domains & Features & Conditions \\
\hline $\begin{array}{l}\text { 1. Canonical } \\
\text { controllers are } \\
\text { present (rather } \\
\text { than absent). }\end{array}$ & $\begin{array}{l}\text { 3. Canonical } \\
\text { targets are } \\
\text { bound (rather } \\
\text { than free). }\end{array}$ & $\begin{array}{l}\text { 7. Canonical } \\
\text { domains are } \\
\text { asymmetric } \\
\text { (rather than } \\
\text { symmetric). }\end{array}$ & $\begin{array}{l}\text { Canonical } \\
\text { features } \\
\text { are lexical } \\
\text { (rather } \\
\text { than non- } \\
\text { lexical). }\end{array}$ & $\begin{array}{l}\text { 11. Features } \\
\text { have no } \\
\text { choice of } \\
\text { feature value }\end{array}$ \\
\hline $\begin{array}{l}\text { 2. Canonical } \\
\text { controllers } \\
\text { overtly express } \\
\text { agreement } \\
\text { features. }\end{array}$ & $\begin{array}{l}\text { 4. Canonical } \\
\text { targets express } \\
\text { agreement via } \\
\text { inflectional } \\
\text { marking } \\
\text { (rather than } \\
\text { via clitics or } \\
\text { free forms). }\end{array}$ & $\begin{array}{l}\text { 8. Canonical } \\
\text { domains are } \\
\text { than non- }\end{array}$ & $\begin{array}{l}\text { lo. } \\
\text { Canonical } \\
\text { features } \\
\text { having } \\
\text { matching } \\
\text { values } \\
\text { lather non- } \\
\text { matching } \\
\text { values). }\end{array}$ & \\
\hline & $\begin{array}{l}\text { 5. Canonical } \\
\text { targets } \\
\text { obligatorily } \\
\text { mark } \\
\text { agreement. }\end{array}$ & & & \\
\hline & $\begin{array}{l}\text { 6. Canonical } \\
\text { targets agree } \\
\text { with a single } \\
\text { controller. }\end{array}$ & & & \\
\hline
\end{tabular}

In the next subsection we shall discuss agreement properties of Esahie.

\section{Agreement in Esahie}

As hinted earlier, Esahie, as an isolating language, is characterized by a limited system of inflection marking. A corollary of this is that, unlike languages such as Swahili and French, where verbs (overtly) agree in person and number with their subjects, in Esahie, and indeed many other Kwa languages, including Akan, Ga, Ewe, Nzema (Osam, 1993; Aboh \& Essegbey, 2010b), subject- 
predicate agreement is not morphologically overt. We illustrate this in the examples below.
a.
Awo tè
a-kolaa
pa.
Awo

$$
\text { COP SG-child }
$$
good

"Awo is a good child."

$\begin{array}{llllll}\text { b. Awo ne } & \text { Blue tè } & \text { y-golaa } & \text { pa. } \\ \text { Awo CONJ Blue COP } & \text { PL-child } & \text { good }\end{array}$

"Awo and Blue are good kids."
a. Mè
krò
nitse-sũã̃-nع.
1SG.SBJ
love.HAB
thing-learn-NOML
"I love studying."
b.
$\mathrm{O}$
3SG.SBJ
krò
love.HAB
nitse-sũã́-n $\varepsilon$.
thing-learn-NOML
"S/he loves studying."

We notice in (9-10) that in Esahie there is no overt realization of agreement between the verbs and the subjects in terms of number and person. In $(9 \mathrm{a}, \mathrm{b})$ the copular verb does not change in form independently from the singular or plural feature of the subject. In $(10 a, b)$, we observe that the verb remains the same irrespective of the person value of the subject pronoun.

Turning to agreement within the DP, since Esahie is predominantly genderless ${ }^{8}$ and caseless $^{9}$, the only relevant morphosyntactic feature that could be possibly examined is number (cf. DP-internal Agreement in Number section). However,

8 Although the animacy system in Kwa is in a way analogous to gender in Romances languages, Broohm (2017) shows that as a result of the non-existence of animacy-based agreement in Esahie, it would be wrong to classify Esahie as a "gender-sensitive" language.

9 Case, on the other hand, cannot be said to be non-existent in Esahie. Its realization, however, is restricted only to the pronominal system, where it is typically marked syntactically via its position in the sentence, rather than via overt morphological exponence. However, there is also morphological exponence, see Table 7

Legon Journal of the Humanities 29.1 (2018) Page | 107 
Broohm, O. N. and Rabanus, S./ Agreement and syncretism in Esahie

in anaphora agreement, as we shall see later, there are further agreement features to be considered (cf. Number, person, animacy, and case agreement of anaphoric pronouns section).

\section{DP-internal agreement (in number)}

As Ameka and Dakubu (2008) rightly observe, there is an interesting split as far as plural formation and nominal classes in Kwa are concerned. They observe that within the Tano group of languages (to which Esahie belongs), there is usually number concord. With specific reference to Esahie, Broohm (2017) confirms this observation and notes that the Esahie DP exhibits some level of agreement morphology as far as number (plural) marking is concerned.

Agreement marking in Esahie may occur between the noun and the head (demonstrative) determiner, as well as between the noun and other (nominal) modifiers within the DP such as adjectives, where the noun functions as the controller while the remaining elements function as targets. In the examples that follow, we shall see how this works.

$\begin{array}{lll}\text { a. Bakaa hé } & \text { b. } & \text { M-makaa }{ }^{10} \text { hé-mo } \\ \text { stick DEM } & \text { PL-stick } & \text { DEM-PL } \\ \text { "This stick." } & \text { "These sticks." }\end{array}$

In example $(11 \mathrm{a}, \mathrm{b})$, we observe that the complement noun and the head demonstrative agree in number, albeit using different markers. In the examples that follow, we shall attempt to introduce other modifiers (demonstratives) into the DP, to be able to better understand how number agreement works within the DP (Broohm, 2017, p. 20).

10 The initial consonant /b/ in bakaa assimilates totally with the plural prefix /m-/. 

a. Boaen tenden hé.
Singular (Ø-marked)

Broohm, O. N. and Rabanus, S./Legon Journal of the Humanities 29.1 (2018)

sheep tall DEM

"This tall sheep."

b. M-moaen n-denden hé-mo.

Plural (nasal-marked) PL-sheep PL-tall DEM-PL

"These tall sheep."

c. * M-moaen tenden hé.

PL-sheep tall DEM

(13) a. Bowie kwekwa kwekwa hene. Singular (Ø-marked) bone dry INT $^{11} \quad$ DEM

"That (very) dry bone."

b. M-mowie n-kwekwa kwekwa hene-mo. Plural (nasal-marked) PL-bone PL-dry INT DEM-PL

"Those dry bones."

c. *M-mowie kwekwa kwekwa hene.

$$
\text { PL-bone dry INT DEM }
$$

a. E-woo pri hé. Singular (vocal-marked) SG-snake big DEM

"This big snake."

b. N-woo m-bri hé-mo. Plural (nasal-marked)

PL-snake PL-big DEM-PL

"These big snakes."

11 The reduplication has intensifier function (INT). 

c. ${ }^{*}$ N-woo pri hé.
PL-snake big DEM

In the examples $(12 \mathrm{~b}, 13 \mathrm{~b}, 14 \mathrm{~b})$, we observe agreement between the controller nouns and the target modifiers (i.e., adjectives and demonstratives). More importantly, we notice that whilst the demonstrative appears to invariably select the suffix $-m$ o in the plural irrespective of the form of plural marker (in this case a nasal prefix $n$-) borne by the controller noun, the adjective (when marked for the plural), usually shares the same marker and marker distribution (i.e., prefix) with the controller noun. Note that the plural prefix $/ \mathrm{n} /$ is a homorganic nasal, and therefore it assimilates in place with the consonant that follows it. This accounts for the variation in the form of the marker in different phonetic contexts. The ungrammaticality of examples $(12 \mathrm{c}, 13 \mathrm{c}$, and 14c) points to the fact that agreement marking is obligatory in these contexts.

With respect to the discussion of morpheme-based versus paradigm-based approaches (cf. Theoretical framework section), in the examples (11-14), plural number agreement is always expressed by affixation, hence, the morphology can be accounted for in terms of morpheme-based morphology. In (15), however, things are different.

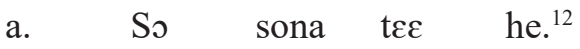
DEM person bad DEM
"This bad person."

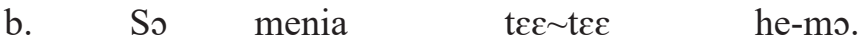
DEM person(PL) bad P PL DEM-PL
"These bad people."

The sentence in (15b) is the plural version of (15a). In the controller noun menia "people" the plural feature is inherent to the lexeme:

12 The double demonstrative strategy appears to increase the "specificity and giveness" of the modified entity. 
plurality is expressed via suppletion. In the targets, the plural agreement feature is expressed in three different manners: overtly as the suffix $-m s$ on the clause-final demonstrative hems; via

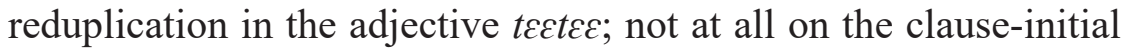
demonstrative so. Hence, in (15) a morpheme-based approach, which requires morphemes with plural meaning on the words in agreement, cannot adequately describe the Esahie agreement system.

Reduplication is particularly instructive in this sense: $t \varepsilon \varepsilon t \varepsilon \varepsilon$ contains two identical syllables. Thus, it is impossible to assign the meaning "plural" to the first and the meaning "bad" to second syllable (cf. [16a]) or vice-versa. Contrastingly, the paradigmbased approach is perfectly in line with the data: the paradigm cell in which the adjective $t \varepsilon \varepsilon$ "bad" is associated with the plural feature determines the application of the reduplication rule, consequently, (16b).

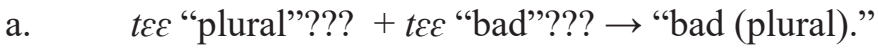

$$
\begin{aligned}
& \text { b. } \quad \text { "bad (plural)." } \rightarrow t \varepsilon \varepsilon \sim t \varepsilon \varepsilon
\end{aligned}
$$

In (17-20) we provide further examples for constructions in which the agreement feature is not always expressed by concatenative morphology. We begin with multiple adjectival targets in (17) and (18).

a. Brasua kokore kama ne.

woman light.skinned good-looking DEF

"The good-looking light-skinned woman."

b. M-mrasua n-kokore kama kama ne-mo.

PL-woman PL-light.skinned PL good-looking DEF-PL

"The good-looking light-skinned women." 
Broohm, O. N. and Rabanus, S./ Agreement and syncretism in Esahie

a. Tena bre pri ne.

cloth black big DEF

'The big black cloth.'

b. N-dena bre m-bri m-bri ne-mo.

PL-cloth black PL-PL PL-big DEF-PL

'The big black cloths.'

c. N-dena bre m-bri-kua ne-mo.

PL-cloth black PL-big-AUG DEF-PL

"The large black cloths."

In example (17b), the plurality feature is overtly expressed on the controller noun brasua "women", as well as on all agreement targets (i.e. the determiner, the adjective of quality kama "goodlooking" [via reduplication], and the colour adjective kokore "lightskinned"). Contrastingly, in example (18b, c), the plurality feature is overtly expressed on the controller noun, the determiner, and the size adjective pri "big" (even redundantly by concatenative morphemes and reduplication, cf. $[15,16])$, but not on the colour adjective bre "black". As far as the overt expression of agreement feature on targets is concerned, colour adjectives in Esahie exhibit an ambivalent behaviour.

In (19) and (20), we consider the behaviour of quantifiers and numerals in agreement morphology, respectively.

a. M-mrandec y-dikaa $\sim$-dikaa pẽe.

$$
\begin{aligned}
& \text { PL-gentleman PL-PL PL-short } \quad \operatorname{many}(\mathrm{PL}) \\
& \text { "Many short gentlemen" }
\end{aligned}
$$

b. M-mrande $\varepsilon \quad n$-den $\sim$-den ne-mo-mu-nyo.

PL-gentleman PL-PL PL-tall DEF-PL-all-2

"Both tall gentlemen." 
In (19a), the plurality feature is overtly expressed on controller noun abrandec "gentleman" and the adjective tikaa "short", but it is an inherent feature of the quantifier pẽe "many". In (19b), apart from the controller noun and adjectival target overtly expressing the relevant feature, the morphological structure of the quantifier ne-mo-mu-nys "both" contains both morphemes with inherent plural features and the overt plural marker $-m$ s. This observation highlights the fact that Esahie quantifiers may have overt agreement markers.

a. M-mrande $\varepsilon$

PL-gentleman n-den n-den nys he-mo.

PL-PL PL-tall 2 DEM-PL

"The two tall gentlemen."

b. M-mabunu anyanza-foc

PL-virgin wise-PL ${ }_{\text {[+HUMAN] }}$

"All the ten wise virgins." bru n'-akoraatí.

10 DEF-all

In example (20a,b), we observe that Esahie numerals, by tendency, fail to participate in overt agreement morphology.

\section{Number, person, animacy, and case agreement of anaphoric pronouns}

It has been noted that NPs may be extracted from various argument and non-argument positions for various $\bar{A}$-operations ${ }^{13}$. The effect of $\bar{A}$-operations varies across languages (Georgi, 2014). While some languages, such as English (Salzmann, 2011), allow for gaps ${ }^{14}$, other languages do not permit or require the use of the gap strategy, instead, they resort to the use of resumptive pronouns (RPs) in the various extraction sites. Additionally, there are languages that

13 Operations involving the extraction of elements from argument positions into non-argument positions for purposes of information structure.

14 The claim for a gap strategy in English finds justification in the fact that the extraction site shows no phonetic traces of such operations.

Legon Journal of the Humanities 29.1 (2018) Page | 113 
Broohm, O. N. and Rabanus, S./ Agreement and syncretism in Esahie allow both RPs and gaps in certain positions (Klein, 2014). In this section, we examine NP resumption as instance of agreement in Esahie. Particularly, we consider NP resumption in two types of A-operations: relativized clauses and focalized constructions. As we shall see, in both types of constructions, RPs agree with moved antecedent NPs. We begin by examining the co-referentiality exhibited between NPs and their modifying relative clauses.

\section{Relative clauses}

Relative clauses in Esahie typically have the structure in (21).

(21) a. $\left[{ }_{\mathrm{IP}}\right.$ Me-nwũ-ne $\left[_{\mathrm{NP}}\right.$ brasua $_{i}\left[{ }_{\mathrm{CP}}\right.$ bo $\left[_{\mathrm{IP}}\right.$ Aseda gya-le-ye $\left.{ }_{i}\right] \quad$ nen. $\left.\left.]\right]\right]$ 1SG-See-PST woman REL Aseda marry-PST-3SG.ANIM.ACC CD "I saw the woman whom Aseda married."

b. $\left[_{\mathrm{IP}}\left[_{\mathrm{NP}}\right.\right.$ Brasua $_{i}\left[\mathrm{CP}_{\mathrm{CP}}\right.$ bo $\left[{ }_{\mathrm{IP}} \mathrm{o}_{i}\right.$-gyale-le Aseda $]$ ne $]$ fi Boako. $]$ woman REL 3SG.ANIM.NOM-marry-PST Aseda CD be.from Boako "The woman who married Aseda is from Boako."

These examples exhibit the salient morphosyntactic properties of Esahie relative clauses. In (21a) the object of the verb $n w \tilde{u}$ "to see" is made up of an initial NP (the antecedent or the head) followed by an embedded clause. This NP + relative-clause structure functions as the object of the sentence. In (21b) the NP+ relative-clause structure functions as the subject of the sentence. In either case, the antecedent NP occurs on the left periphery of the clause and is followed by the relative clause marker $b$. The relative marker is then followed by a complement IP that is in turn followed by the clause-final determiner nen, which is the same as the definite determiner in Esahie.

Inside the complement IP in (21a) is the RP ye "him/ her" which is co-referential with the head NP and agrees with 
Broohm, O. N. and Rabanus, S./ Legon Journal of the Humanities 29.1 (2018) it in animacy, number, ${ }^{15}$ person, and case. The controller in this agreement relation is the head NP brasua "women", the RP plays the role of target. The RP occupies the canonical position of the relativized element (i.e., the object position in this case). In (21b) it is the subject position in the relative clause that is relativized, and we see a subject RP $o^{-}$"s/he" in the subject position in the complement clause. Functioning as the target, the resumptive pronoun, similarly, agrees with the controller (i.e, the antecedent head NP) in animacy, number, person, and case: $\{3 \mathrm{sG}, \mathrm{ANIM}, \mathrm{NOM}\}$. The domain of agreement is intra-sentential (within the clause).

\section{Focalizations}

Another $\bar{A}$-operation that licenses agreement via NP resumption is focalization. In Esahie, and indeed many other Kwa languages (Akan: Korsah, 2016; Yoruba: Adesola, 2010), gaps are disallowed in extraction sites in certain contexts. As Broohm (2014) observes, the RP is always obligatory when the argument in focus is 'animate' and 'human'. In the example(s) below, we consider both subject and object resumption as a concomitant of an $\bar{A}$-operation of focalization.

\section{Non-focused sentence}

$\begin{array}{ll}\text { a. Kofi fõã-ne } & \text { Yaa. } \\ \text { Kofi chase-PAST } & \text { Yaa } \\ & \text { "Kofi chased out Yaa." }\end{array}$

15 Even in syncretic forms, if an antecedent singular NP is replaced with its syncretic plural counter part, the form of the RP changes to reflect the change in number (i.e. number agreement). There is a different pronoun for stone and stones. This is illustrated in the example below:

$$
\begin{aligned}
& \text { a. Nyoboc he bo o-to-le asecwo nen. } \\
& \text { stone DEM REL 3SG.INANIM.NOM-fall-PST ground CD } \\
& \text { "This stone that fell on the ground." }
\end{aligned}
$$

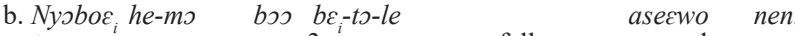

$$
\begin{aligned}
& \text { stone DEM-PL REL 3PL.INANIM.NOM-fall-PST ground CD } \\
& \text { "These stones that fell on the ground." }
\end{aligned}
$$




\title{
Subject-focused version of (22a)
}

b. Kofi ${ }_{j} \quad$ ye $\varepsilon{ }^{*} \varnothing_{\mathrm{j}} / \rho_{j}=$ fõã-ne Yaa-っ.

Kofi(ANIM)[NOM] FOC $* ø / 3$ SG.NOM.ANIM=chase-PST Yaa-CD

"KOFI [and not, say, Kwame] chased out Yaa."

\section{Object-focused version of (22a)}

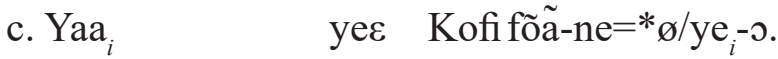 \\ Yaa(ANIM)[ACC] FOC Kofichase-PST $=* \varnothing / 3$ SG.ACC.ANIM-CD \\ "Kofi chased out YAA [and not, say, Afia]."
}

Returning to our discussion on agreement, we notice that the RP clitic ${ }^{16}$ agrees with its referent NP (antecedent) in terms of number, person, animacy, and also case features. For instance, Kofi in (22b) is a singular animate NP which has been extracted from a subject position, and thus has nominative case. Yaa in (22c) has similar properties except that, because it is extracted from an object position, it has accusative case. The extracted antecedent NPs in this case function as the controller, while the RP clitics, $\mathrm{o}$ - (nominative) and ye- (accusative), function as the target, and the features at play here are number, person, animacy and case. The domain of agreement is extra-sentential (beyond the clause).

\section{Canonicity of agreement in Esahie}

In this section, we consider the two kinds of agreement earlier discussed in the light of Corbett's criteria of canonicity. The goal of this section is to test the strength of each kind of agreement, and also to compare and contrast the two kinds of agreement using Corbett's criteria (see Table 1 above for a more detailed formulation of the criteria).

16 The RP is considered a clitic because it is phonologically dependent on the verb, and, as a result, it shows the effects of vowel harmony with the verb and its other prefixes.

Legon Journal of the Humanities 29.1 (2018)

Page | 116 
Broohm, O. N. and Rabanus, S./ Legon Journal of the Humanities 29.1 (2018)

Table 2: Canonicity of agreement in Esahie

\begin{tabular}{|l|c|c|}
\hline \multicolumn{1}{|c|}{ Canonicity criteria } & $\begin{array}{c}\text { DP-internal } \\
\text { agreement }\end{array}$ & $\begin{array}{c}\text { Anaphora } \\
\text { agreement }\end{array}$ \\
\hline 1. Controller is present. & $\sqrt{ }$ & $\sqrt{ }$ \\
\hline 2. $\begin{array}{l}\text { Controller overtly expresses } \\
\text { agreement features. }\end{array}$ & $\sqrt{ }$ & $\mathrm{X}$ \\
\hline 3. $\begin{array}{l}\text { Expression of agreement on the target: } \\
\text { bound }>\text { free }\end{array}$ & $\sqrt{ }$ & $\mathrm{X}$ \\
\hline 4. $\begin{array}{l}\text { Expression of agreement on target: } \\
\text { inflectional marking (affix) }>\text { clitic }> \\
\text { free word }\end{array}$ & $\sqrt{ }$ & $\sqrt{ }$ \\
\hline 5. $\quad \begin{array}{l}\text { Target obligatorily marks agreement. } \\
\text { 6. Target agrees with a single controller. }\end{array}$ & $\sqrt{ }$ & $\sqrt{ }$ \\
\hline 7. $\quad$ Domain is asymmetric. & $\sqrt{ }$ & $\mathrm{X}$ \\
\hline 8. $\quad$ Domain is local. & $\mathrm{X}$ & $\mathrm{X}$ \\
\hline 9. $\begin{array}{l}\text { Feature is lexical (rather than non- } \\
\text { lexical) }\end{array}$ & $\sqrt{ }$ & $\sqrt{ }$ \\
\hline 10. Features have matching values. & & $\sqrt{ }$ \\
\hline 11. Features have no choice of feature \\
value.
\end{tabular}

From the data discussed above, we notice that a DP-internal complement noun, such as boaen "sheep" in (12), functions as the controller of (number) agreement within the DP, whilst an (antecedent) referent NP, such as Kofi/Yaa in (22), functions as the controller of anaphora agreement. In both instances, the controller is present, implying that both are equally canonical (criterion 1). With respect to agreement within the DP, we also observe that whilst the controller noun typically expresses the number feature overtly via the plural prefix [m-] in mmoaen "sheep" as in (12b), on the contrary, in anaphora agreement, the controller, i.e. the referent NP, does not overtly express the relevant feature(s). DP-internal agreement is therefore more canonical (criterion 2).

In terms of the morphological distribution of the agreement marker(s) expressed on the targets, we notice that in both types 
of agreement, agreement markers (i.e. affixes in DP-internal agreement and clitics in anaphora agreement) are bound rather than free (criterion 3). Given the canonicity ranking: inflectional marking (affix) $>$ clitic $>$ free word (cf. Corbett, 2003, p. 113), the expression of agreement in DP-internal agreement targets (affixes) is more canonical than expression of agreement in anaphora agreement targets (RP clitics) (criterion 4).

Relative to the obligatory expression of agreement on the target(s), we notice that while DP-internal modifiers (targets of DPinternal agreement) overtly express agreement, RP clitics (targets of anaphora agreement) covertly express the same, so either way, agreement is obligatorily expressed by/in the target, both are therefore equally canonical in this regard (criterion 5). Also, targets of both types of agreement agree with single controllers, an (antecedent) referent NP in the case of anaphora relations and a noun in the case of DP-internal agreement. The data discussed above shows no evidence of multiple controllers. They are at par in this regard (criterion 6).

The assumption of the distinctive roles of controllers and targets implies as an inherent asymmetric relation, rather than a balanced or symmetrical relation. The controllers (i.e. antecedent referent NPS and DP-internal complement nouns) determine the form of the targets (i.e. RP clitics and DP-internal modifiers) and the reverse is not possible (criterion 7). Domains: DP-internal agreement is local, since it is at the phrasal-level, while anaphora agreement is non-local since it is beyond the clause ${ }^{17}$. DP-internal agreement is therefore more canonical (criterion 8).

The features in both types of agreement are based mostly on formal assignment from outside rather than being purely lexical (with the exception of animacy) (criterion 9). Features in both types of agreement are therefore equally canonical. As expected, agreement features for types have matching values (criterion 10).

17 As Corbett (2006) explains, agreement at the phrasal/clausal level is local, whilst agreement beyond the clause is non-local. 
Broohm, O. N. and Rabanus, S./ Legon Journal of the Humanities 29.1 (2018)

Finally, we see no effect of the conditions on the choice of the values and, hence, no differences between DP-internal and anaphora agreement (criterion 11).

Given the facts summarised above, we conclude that in Esahie, DP-internal agreement (with respect to number) is more canonical than anaphora agreement. According to Corbett (p.c.), this conclusion fits perfectly into what is expected, "since the bonds within the DP are closer than any external ones". Anaphora agreement, nonetheless, is more interesting because of the heterogeneity of the interacting features. In the light of the discussions provided above on the operation and canonicity of agreement in Esahie, we consider the inflectional system of the Esahie nominal domain as fairly robust.

Having evaluated the strength and robustness of the inflectional system of the nominal domain in Esahie against agreement, we now proceed to look at syncretism in the nominal domain, as a point of contrast, showing the paucity of inflection marking in the nominal domain of Esahie. The purpose of this contrast is to provide a comprehensive account of the inflection marking in the nominal domain of Esahie.

\section{Syncretism}

Syncretism raises a number of issues against the fundamental assumptions of morpheme-based approaches. With syncretism, "a single form serves two or more morpho-syntactic functions" (Baerman et al, 2005, p. 2). Put differently, two or more cells within a word's paradigm are occupied by a single form. Syncretism arises where the morphology of a language fails to show a distinction that is made in the syntax.

Instances of syncretism are typically found in person/ number marking in verbal paradigms and case marking in nominal paradigms. In Rumanian, for instance, verbs of all classes exhibit syncretism of the first person singular with the first person plural form in the imperfect tense, hence, number syncretism, see Table 3 below. 
Broohm, O. N. and Rabanus, S./ Agreement and syncretism in Esahie

Table 3: Imperfect paradigms of Rumanian verb forms (Stump, 2001, p. 215)

\begin{tabular}{|c|c|c|}
\hline & a cânta "to sing" & a auzi "to hear" \\
\hline $1 \mathrm{SG}$ & $\begin{array}{l}\text { cântá-m } \\
\text { "I sing" }\end{array}$ & $\begin{array}{l}\text { auziá-m } \\
\text { "I hear" }\end{array}$ \\
\hline $2 S G$ & $\begin{array}{l}\text { cântá-i } \\
\text { "you sing" }\end{array}$ & $\begin{array}{l}\text { auziá-i } \\
\text { "you hear" }\end{array}$ \\
\hline 3SG & $\begin{array}{l}\text { cântá } \\
\text { "she/it sings" }\end{array}$ & $\begin{array}{l}\text { auziá } \\
\text { "she/it hears" }\end{array}$ \\
\hline 1PL & $\begin{array}{l}\text { cântá-m } \\
\text { "we sing" }\end{array}$ & $\begin{array}{l}\text { auziá-m } \\
\text { "we hear" }\end{array}$ \\
\hline 2PL & $\begin{array}{l}\text { cântá-tI } \\
\text { "you sing" }\end{array}$ & $\begin{array}{l}\text { auziá-ti } \\
\text { "you hear" }\end{array}$ \\
\hline 3PL & $\begin{array}{l}\text { cântá-u } \\
\text { "they sing" }\end{array}$ & $\begin{array}{l}\text { auziá-u } \\
\text { "they hear" }\end{array}$ \\
\hline
\end{tabular}

As earlier stated, case systems also easily lend themselves to syncretism. In the Yir-Yoront (Pama-Nyungan Australian language) data provided below, while words such as "foot" or "leg" have distinct forms for absolutive, ergative and dative case, words such as "arm" and "armpit", on the contrary, fail to make the expected distinction between ergative and dative. Words in the latter category are clearly instantiations of case syncretism, see Table 4. 
Broohm, O. N. and Rabanus, S./ Legon Journal of the Humanities 29.1 (2018)

Table 4: Case syncretism in Yir-Yoront (Alpher 1991, cited in Baerman, 2007, p. 1)

\begin{tabular}{|l|l|l|l|l|}
\hline & "foot" & "leg" & "arm" & "armpit" \\
\hline ABS & thaml & kumn & puth & ngamrr \\
\hline ERG & thamarr & kumalh & putha & ngumurr \\
\hline DAT & thamarriy & kuman & putha & ngumurr \\
\hline
\end{tabular}

It is instructive to mention at this point that the typology of syncretism may be approached from a formal and/or an explanatory perspective(s). From a formal perspective, syncretism may be typologized as being simple, nested or contrary (Baerman et. al, 2005, p. 13-16). For purposes of space and theoretical alignment, however, this paper approaches the subject only from an explanatory perspective. Adopting an explanatory approach to the typology of syncretism, Stump (2016) proposes three typologies of syncretism: natural-class syncretism, directional syncretism, and morphomic syncretism.

In natural-class syncretism, syncretic forms in a lexeme's paradigm share a common feature and could be seen as constituting a natural-class. Instantiations of this kind of syncretism involve cells that have a common feature value (say, singular number). Let us consider the Italian example in Table 5.

Table 5: Present tense paradigms of the Italian verb ballare "dance"

\begin{tabular}{|c|c|c|}
\hline & PRS.IND & PRS.SBJV \\
\hline 1SG & ballo & balli \\
\hline 2SG & balli & balli \\
\hline 3SG & balla & balli \\
\hline 1PL & balliamo & balliamo \\
\hline 2PL & ballate & balliate \\
\hline 3PL & ballano & ballino \\
\hline
\end{tabular}


The syncretic forms of Italian verbs as shown in the shaded cells in the table all share a common value in number (singular), tense (present) and mood (subjunctive), hence, they form a natural class. As Stump (2016) points out, instances of natural-class syncretism, as observed in the Italian verbal paradigm, may be explained either as being simply a reflection of a kind of impoverishment in the rules of exponence, resulting from the fact that the morphosyntactic distinction relevant for syntax and semantics are simply unavailable for realization by the language's (inflectional) morphology, or preferably, as cases of underspecification, in which case the syncretic forms may be seen as being underspecified for, e.g., person (as in Table 5).

In directional syncretism, there is a sort of "parasitic" relation, since one cell appears to rely on another for its realization. One member of such a relation may be seen as the determinant member of the syncretic pair while the other is seen as the dependent member. In the Italian example shown in Table 6, syncretism can be said to be directional because the third person plural form (the dependent, "parasite") is parasitic to the third person singular form (the determinant).

Table 6: Present paradigm of màgnare "eat" in Italian, Verona dialect (Bondardo, 1972, p. 150)

\begin{tabular}{|c|c|c|}
\hline & SG & PL \\
\hline $\mathbf{1}$ & màgno & magnémo \\
\hline $\mathbf{2}$ & màgni & magne \\
\hline $\mathbf{3}$ & màgna & màgna \\
\hline
\end{tabular}

The Rumanian example shown in Table 3 is another example of a directional syncretism In this case, the first person singular form is dependent on the first person plural form, historically marked in the Romance languages (and, generally, in the Indo-European languages) by the bilabial nasal $/ \mathrm{m} /$. 
In addition to situations where syncretic forms constitute a coherent class of morphosyntactic properties (natural-class syncretism), and situations where pairs of syncretic forms exhibit a sort of directionality (directional syncretism), there are also instances of syncretism where the relation between pairs of syncretic forms may be seen as symmetrical, in that neither pair derives its exponence from the other pair. This type of syncretism has been called morphomic or symmetrical syncretism (Stump, 2016, p. 179).

The data on syncretism discussed above challenges the morpheme-based approach and provides further evidence for the paradigm-based approach presented in Section 2.0. In order to account for the ergative/dative syncretism in Yir-Yoront (Table 4) and the third person singular/plural syncretism in Italian (Verona dialect) (Table 6) paradigms are "irreducible" because they identify patterns in which two different paradigm cell license the same word forms. For the third person singular/plural syncretism in Italian, morpheme-based accounts would try to model the relationship between content and formal exponence in the following way (cf. [2a] in the Theoretical framework section):

$$
\begin{aligned}
& \text { a. magnà "eat" }+\varnothing 3 \mathrm{SG} ? ? ? \rightarrow \text { "he eats." } \\
& \text { b. magnà "eat" }+\varnothing 3 \mathrm{PL} ? ? ? \rightarrow \text { "they eat." }
\end{aligned}
$$

The assumption that there is a zero morpheme which has two different grammatical meanings (3SG vs. 3PL) is highly problematic because it violates the principle of morpheme-based approaches that the "grammatical and semantic content of an inflected word form is fully determined by its representation as a combination of morphemes". Contrastingly, it is perfectly correct to assume that the two different paradigm cells are associated with the same inflected word form (cf. [2b] in the Theoretical framework section):

$$
\begin{aligned}
& \text { a. "he eats." } \rightarrow \text { magnà } \\
& \text { b. "they eat." } \rightarrow \text { magnà }
\end{aligned}
$$


Broohm, O. N. and Rabanus, S./ Agreement and syncretism in Esahie Hence, paradigms play a crucial role in explaining the interaction between inflectional morphology and other modules of grammar.

\section{Syncretism in Esahie}

In this section, we examine various instances of syncretism in Esahie, and attempt to provide an analysis of these instances in the sense of Stump's (2016) typology. In particular, we consider instances of syncretism in the pronominal system (cf. Syncretism in the Esahie pronominal system section) as well as in some frozen nominal forms in Esahie (cf. Number syncretism in nominal forms section).

\section{Syncretism in the Esahie pronominal system}

In this section we limit our discussion to syncretism within the pronominal system of Esahie. We first examine case, animacy, and person syncretism, and then proceed study number syncretism.

\section{Case and animacy syncretism in personal pronouns}

Notwithstanding that lexical DPs are not marked for case, the Esahie pronominal system is sensitive to case. For the pronominal system, the relevant distinctions are made for nominative and accusative case. In Table 7 below, based on data collected in a fieldwork, we show the various case/animacy paradigms of the pronominal system. Cells with syncretic forms are shaded with the same grey-scale values for purposes of identification. From the table, we observe that there are several instances of syncretism in the pronominal system of Esahie. Chief among them are third person forms. First, in Esahie - unlike in Akan (Asante) (Korsah, 2016) - there is no animacy distinction in the third person paradigm. With respect to case, we notice that similarly, there is no distinction between first person nominative and accusative forms (neither in singular nor in plural number), second person plural nominative and accusative forms, as well as third person plural nominative and accusative forms: indeed, in none of the plural pronouns. 
Broohm, O. N. and Rabanus, S./ Legon Journal of the Humanities 29.1 (2018)

Table 7: Case and animacy syncretism in Esahie

\begin{tabular}{|c|c|c|c|c|}
\hline & \multicolumn{2}{|c|}{ Nominative } & \multicolumn{2}{c|}{ Accusative } \\
& Singular & Plural & Singular & Plural \\
\hline $\mathbf{1}$ & me & y $\varepsilon$ & me & y \\
\hline $\mathbf{2}$ & $\varepsilon$ & $\varepsilon m s$ & w & em \\
\hline $\mathbf{3}$ + ANIM & 0 & $\mathrm{~b} \varepsilon$ & ye & $\mathrm{b} \varepsilon$ \\
\hline $\mathbf{3}$-ANIM & 0 & $\mathrm{~b} \varepsilon$ & ye & $\mathrm{b} \varepsilon$ \\
\hline
\end{tabular}

The syncretism in animacy, evidenced by the lack of distinction with respect to animacy across the entire third person paradigm, may be explained as instantiation of natural-class syncretism, in that each set of syncretic forms, say the set of third singular nominative forms, constitutes a coherent class of morphosyntactic properties, collectively identifiable by the feature $\{3 \mathrm{SG}, \mathrm{NOM}\}$.

Alternatively, this syncretism may also be conveniently attributed to underspecification, or as resulting from an impoverishment in the inflectional system of Esahie by which morphosyntactic distinctions that are relevant for syntax and semantics are unavailable for realization.

The syncretism in case as observed in the form pairs of 1SG nominative/accusative form, 1PL nominative/accusative, 2PL nominative/accusative, and 3PL nominative/accusative may be typologized as representing directional syncretism, because there appears to be a sort of parasitic relation. Konig (2008) observes that in African languages with an accusative (as opposed to ergative) alignment, as is the situation in case-marking African languages, nominative is the unmarked or default case. She explains that the nominative case is unmarked on three levels - in morphology, function, and citation. It is morphologically unmarked because it is typically zero-marked, and functionally unmarked because it is used in a wider range of contexts.

Assuming along the lines of König (2008), we argue that the accusative forms of the each pair (in Table 7) rely on its nominative counterpart for its realization. This type of syncretism can arise as a corollary of a property mapping that causes the morphosyntactic property set: $\{1 \mathrm{SG}, \mathrm{ACC}\},\{1 \mathrm{PL}, \mathrm{ACC}\},\{2 \mathrm{PL}, \mathrm{ACC}\}$ and $\{3 \mathrm{PL}, \mathrm{ACC}\}$, 
which are relevant for syntax and semantics to be realized by means of the morphology that is usual for realizing a contrasting property set: $\{1 \mathrm{SG}, \mathrm{NOM}\},\{1 \mathrm{PL}, \mathrm{NOM}\},\{2 \mathrm{PL}, \mathrm{NOM}\}$ and $\{3 \mathrm{PL}, \mathrm{NOM}\}$, respectively.

The mapping of property that results in this kind of syncretism is illustrated in Table 8 below. We see here that the cells of the content paradigm, (the requirement of syntax) outnumber the cells in form paradigm (the morphological realizations).

Table 8: Property mapping in case syncretism

\begin{tabular}{|c|c|c|}
\hline Content Paradigm & Paradigm Linkage & Form Paradigm \\
\hline$<\mathrm{ME},\{1 \mathrm{sG}, \mathrm{NOM}\}>$ & $\rightarrow$ & \\
\hline$<\mathrm{ME},\{1 \mathrm{SG}, \mathrm{ACC}\}>$ & $\rightarrow$ & $<\mathrm{me},\{1 \mathrm{sG}, \mathrm{NOM}\}>$ \\
\hline$<\mathrm{Y} \varepsilon,\{1 \mathrm{PL}, \mathrm{NOM}\}>$ & $\rightarrow$ & \\
\hline$<\mathrm{Y} \varepsilon,\{1 \mathrm{PL}, \mathrm{ACC}\}>$ & $\rightarrow$ & $<\mathrm{y} \varepsilon,\{1 \mathrm{PL}, \mathrm{NOM}\}>$ \\
\hline$<\varepsilon \mathrm{M} \rho,\{2 \mathrm{PL}, \mathrm{NOM}\}>$ & $\rightarrow$ & \\
\hline$<\varepsilon \mathrm{M} \rho,\{2 \mathrm{PL}, \mathrm{ACC}\}>$ & $\rightarrow$ & $<\varepsilon \mathrm{m} \supset,\{2 \mathrm{PL}, \mathrm{NOM}\}>$ \\
\hline$<\mathrm{B} \varepsilon,\{3 \mathrm{PL}, \mathrm{NOM}\}>$ & $\rightarrow$ & \\
\hline$<\mathrm{B} \varepsilon,\{3 \mathrm{PL}, \mathrm{ACC}\}>$ & $\rightarrow$ & $<\mathrm{b} \varepsilon,\{3 \mathrm{PL}, \mathrm{NOM}\}>$ \\
\hline
\end{tabular}

We now proceed to look at number syncretism still within the pronominal system. We analyse a different class of data - reflexive pronouns. The motivation for separating this section from the one earlier discussed is that, here, a different (explanatory) typology is proffered to account for this type of syncretism. 


\section{Number syncretism in reflexives}

In this section, we consider Esahie reflexive pronouns. These reflexives are free pronouns formed via the concatenation of personal pronouns (such as 'my/your') and the form for "self" with a [[pronoun $\left.\left.{ }_{\text {ACCUSATIVE }}\right]+[\text { ["self”] }]_{\text {REFLEXIVE }}\right]$ morphological structure. Different from personal pronouns, reflexive pronouns present evidence of another kind of syncretism: number syncretism, limited to $2 \mathrm{PL}$ and $3 \mathrm{PL}$ forms, which show no distinction. Let us consider Table 9.

Table 9: Number syncretism in reflexive pronouns

\begin{tabular}{|c|c|c|}
\hline Person & Singular & Plural \\
\hline $\mathbf{1}$ & me-nwo & ye-nwo \\
& "myself" & "ourselves" \\
\hline $\mathbf{2}$ & Wo-nwo & be-nwo \\
& "yourself" & "yourselves" \\
\hline $\mathbf{3}$ & $\begin{array}{c}\text { ye-nwo } \\
\text { "him/her/itself" }\end{array}$ & "themselves" \\
\hline
\end{tabular}

The syncretism observed in the 2PL and 3PL reflexive forms could be described as an instantiation of morphomic syncretism, i.e., the relation between pairs of syncretic forms may be seen as symmetrical, in that neither pair derives its exponence from the other pair. None of the syncretized property sets, neither $\{2 \mathrm{PL}, \mathrm{REFL}\}$ nor $\{3 \mathrm{PL}, \mathrm{REFL}\}$, has a stronger claim to the shared morphology than the other property set.

\section{Number syncretism in nominal forms}

Another instance of syncretism in Esahie is number syncretism in nominal forms. It appears that the semantic feature of animacy plays a crucial role in accounting for this instance of syncretism. While animate nouns tend to make distinctions in 
Broohm, O. N. and Rabanus, S./ Agreement and syncretism in Esahie number, inanimate ones are, by tendency, syncretic. This observation is in consonance with Alber and Rabanus' (2011) animacy hierarchy hypothesis according to which the more animated a category - the fewer the number of syncretisms. Osam (1996) proposes a similar hierarchy for Akan. This constraint explains why the examples in the shaded cells in Table 10, which all refer to inanimate reference objects, make no distinction in number, though required by syntax. It is instructive to point out that this shows the interplay between inflectional morphology and syntax-semantics.

Table 10: Number syncretism in Esahie nominal forms

\begin{tabular}{|c|c|c|}
\hline Gloss & Singular & Plural \\
\hline "building" & sua & sua \\
\hline "stone" & nyəboc & nyəboc \\
\hline "squirrel" & ebote & mmote \\
\hline "thief" & awienic & awiefus \\
\hline "rope" & yamaa & yamaa \\
\hline "food" & alic & alic \\
\hline "war" & kog & ahoe \\
\hline "day" & kyĩa & kyĩa \\
\hline "farm" & boo & boo \\
\hline "child" & akslaa & ygslaa \\
\hline "land" & ase & asec \\
\hline "leaf" & nyaa & nyaa \\
\hline
\end{tabular}

This kind of syncretism could be simply attributed to a deficiency in the inflectional system of Esahie, such that the morphosyntactic distinctions relevant for syntax and semantics are simply unavailable for these lexemes. Alternatively, these instances of syncretism may be accounted for as natural-class syncretism involving underspecification. The syncretic forms may thus be seen as being underspecified for number, since their true value becomes clear only when they are used in context. We prefer the latter account, because the former cannot be sustained in the light 
of the fact that, in principle, morphological number distinctions are available in the Esahie inflectional system.

From the two cases of syncretism that have been examined, it becomes clear that paradigms are crucial to inflectional morphology. The Esahie data, therefore, provides empirical support for the irreducibility hypothesis proposed by Stump (2016), which asserts that some morphologically significant generalizations irreducibly pertain to whole word forms and their content (paradigms), rather than to stems, affixes, morphotactics, or syntagmatic operations. In (25), we model syncretism in Esahie in the paradigm-based approach exactly as we did for the Italian dialect in (24):

$$
\begin{aligned}
& \text { a. "stone." } \rightarrow \text { nyoboc } \\
& \text { b. "stones." } \rightarrow \text { nyəboc }
\end{aligned}
$$

\section{Conclusion}

This work set out to investigate two inflectional issues in Esahie - agreement and syncretism. In this work, we have shown that features including number, person, animacy, and case all enter the Esahie agreement system in various contexts. Adopting Corbett's (2006) criteria for canonicity of agreement, this work has shown that in Esahie, DP-internal agreement is more canonical than the various instances of anaphora agreement. Overall, the inflectional system of the nominal of Esahie could be described as fairly robust, relatively speaking. As we hope to have shown from our analyses of agreement and syncretism, the Esahie data provides further empirical support for Stump's (2016) irreducibility hypothesis, which proposes that some morphologically significant generalizations irreducibly pertain to whole word forms and their paradigms, rather than to stems, affixes or morphotactics. Hence, on the theoretical level, although admitting that there are many other ways to account for these mappings, we believe that a paradigmbased approach is more adequate for modelling inflectional morphology than a morpheme-based approach. 
Broohm, O. N. and Rabanus, S./ Agreement and syncretism in Esahie

\section{References}

Aboh, E. O., \& Essegbey, J. (2010a). General properties of the clause. In E. O. Aboh \& J. Essegbey (Eds.), Topics in Kwa syntax (pp. 39-64). Dordrecht: Springer.

Aboh, E. O., \& Essegbey, J. (2010b). Topics in Kwa syntax (Studies in Natural Language and Linguistic Theory 78). Dordrecht: Springer.

Adesola, O. (2010). The non-agreeing subject resumptive pronoun in Yoruba. In E. O. Aboh \& J. Essegbey (Eds.), Topics in Kwa syntax. (Pp. 65-89). Dordrecht: Springer.

Alber, B., \& Rabanus, S. (2011). Kasussynkretismus und Belebtheit in germanischen Pronominalparadigmen. In E. Glaser, J. E. Schmidt $\&$ N. Frey (Eds.), Dynamik des Dialekts - Wandel und Variation (pp. 23-46). Akten des 3. Kongresses der Internationalen Gesellschaft für Dialektologie des Deutschen (IGDD). Stuttgart: Steiner.

Alpher, B. (1991). Yir-Yoront lexicon: Sketch and dictionary of an Australian language. Berlin: Mouton de Gruyter.

Ameka, F., \& Dakubu, M. E. K. (2008). Aspect and modality in Kwa languages. Amsterdam: John Benjamins.

Baerman, M., Dunstan, B, \& Greville G. C. (2005). The syntax-morphology interface: A study of syncretism. (Cambridge Studies in Linguistics 109). Cambridge, UK: Cambridge University Press

Baerman, M. (2007). Syncretism. Language and Linguistics Compass, 1(5), $539-551$.

Bondardo, M. (1972). The Veronese dialect: Features of historical and descriptive grammar. Verona: Veronese Vita.

Broohm, O. N. (2014). Information structure in Esahie. (MPhil. thesis). University of Ghana, Accra.

Broohm, O. N. (2017). Noun classification in Esahie. Ghana Journal of Linguistics, (6)3, 81-122. doi: 10.4314/gjl.v6i3.4

Corbett, G. G. (2003). Agreement: Canonical instances and the extent of the phenomenon. In G. Booji, J. DeCesaris, A. Ralli \& S. Scalise (Eds.), Topics in morphology: Selected papers from the third Mediterranean morphology meeting (Barcelona, September 20-22, 2001) (pp. 109129). Barcelona: Universitat Pompeu Fabra.

Corbett, G. G. (2006). Agreement. Cambridge, UK: Cambridge University Press.

Dolphyne, F. A., \& Dakubu, M. E. K, (1988). The Volta-Comoe languages. In M. E. K. Dakubu (Ed.), The languages of Ghana (pp. 50-90). London: Kegan Paul International.

Frimpong, V. (2009). Aspects of Esahie phonology: An autosegmental analysis. (MPhil thesis). University of Ghana, Accra 
Broohm, O. N. and Rabanus, S./ Legon Journal of the Humanities 29.1 (2018)

Georgi, D. (2014). Opaque interactions of merge and agree. On the nature and order of elementary operations. (Doctoral dissertation). Universität Leipzig, Germany.

Hockett, C. F. (1954). Two models of grammatical description. Word, 10, 210234.

Klein, T. (2014). Deriving a typology of resumption. In A. Assmann, S. Bank, D. Georgi, T. Klein, P. Weisser \& E. Zimmermann (Eds.), Topics at InFL (Linguistische Arbeits Berichte 92) (pp.233-249). Institut für Linguistik: Universität Leipzig.

König, C. (2008). The marked-nominative languages of eastern Africa. In B. Heine \& D. Nurse (Eds.), A linguistic geography of Africa (Cambridge Approaches to Language Contact) (pp. 251-271). Cambridge, UK: Cambridge University Press.

Korsah, S. (2016). Beyond resumptives and expletives in Akan. In D. L. Payne, S. Pacchiarotti \& M. Bosire (Eds.), Diversity in African languages (pp. 103-117). Berlin: Language Science Press.

Lieber, R. (1992). Deconstructing morphology: Word formation in syntactic theory. Chicago: The University of Chicago Press.

Ntumy, S. K., \& Boafo, E. (2002). SIL Interaction. A summary report of African studies. University of Ghana, Accra.

Osam, E. K. (1993). The loss of the noun class system in Akan. Acta Linguistica Hafniensia, 17, 81-105.

Osam, E. K. (1996). Animacy distinctions in Akan grammar. Studies in Linguistic Sciences, 23(2), 153-164

Salzmann, M. (2011). Silent resumptives in Zurich German possessor relativization. In M. Wratil \& P. Gallmann (Eds.), Null pronouns (pp.141-221). Berlin: De Gruyter Mouton.

Steele, S. (1978). Word order variation: A typological study. In J. H. Greenberg, C. Ferguson \& E. Moravcsik (Eds.), Universals of human language, IV: Syntax (pp. 585-623). Stanford: Stanford University Press.

Stump, G. T. (2001). Inflectional morphology. Cambridge, UK: Cambridge University Press.

Stump, G. T. (2016). Inflectional paradigms: Content and form at the syntaxmorphology interface. Cambridge, UK: Cambridge University Press 